\title{
Cold-water corals in the Cap de Creus canyon, northwestern Mediterranean: spatial distribution, density and anthropogenic impact
}

\author{
Covadonga Orejas ${ }^{1,4, *}$, Andrea Gori ${ }^{1}$, Claudio Lo Iacono ${ }^{2}$, Pere Puig ${ }^{1}$, \\ Josep-Maria Gili ${ }^{1}$, Mark R. T. Dale ${ }^{3}$ \\ ${ }^{1}$ Instituto de Ciencias del Mar (CSIC), Pg Maritim de la Barceloneta 37-49, 08003 Barcelona, Spain \\ ${ }^{2}$ Unidad de Tecnología Marina (CSIC), Pg Maritim de la Barceloneta 37-49, 08003 Barcelona, Spain \\ ${ }^{3}$ University of Northern British Columbia (UNBC), 3333 University Way, Prince George, British Columbia V2N 4Z9, Canada \\ ${ }^{4}$ Centro Oceanográfico de Santander (IEO) Promontorio de San Martin s/n, 93004 Santander, Spain
}

\begin{abstract}
The occurrence and density of 3 cold-water coral (CWC) species (Madrepora oculata, Lophelia pertusa and Dendrophyllia cornigera) were investigated in the Cap de Creus canyon (northwestern Mediterranean) by conducting and analysing 22 video survey transects. Species distribution patterns were also investigated at 3 spatial extents $(\mathrm{km}, 100 \mathrm{~s}$ of $\mathrm{m}$ and $\mathrm{m})$ across 3 of the transects using spatial statistics. Additionally, the locations of snagged benthic long-line fishing gear were logged across these 3 transects. Video surveys were carried out by both remotely operated vehicles (ROVs) and the JAGO manned submersible. CWCs were present in 15 of the 22 survey transects, predominantly those covering areas with hard substrate (boulders or hardrock outcrops). M. oculata was the most abundant CWC species in the survey transects, whereas L. pertusa and D. cornigera were much more sparsely distributed, with only isolated colonies observed in the majority of transects. $M$. oculata showed a significant contagious distribution pattern across the analysed transects, with several scales of spatial pattern and patch size being detected, whereas $L$. pertusa and D. cornigera were not found in sufficient numbers to apply spatial statistics. Different covariance patterns were found across the transects between snagged fishing gear and the presence of M. oculata. Further investigation of this relationship and the level of hazard posed by long-line fishing to $M$. oculata colonies is required prior to development of a protective management strategy.
\end{abstract}

KEY WORDS: Cold water corals $\cdot$ Submarine canyons $\cdot$ ROVs $\cdot$ Manned submersible $\cdot$ Population density $\cdot$ Spatial statistic $\cdot$ Spatial patterns $\cdot$ Patch size

\section{INTRODUCTION}

Over the last 2 decades, a significant body of research has focused upon improving our understanding of coldwater coral (CWC) distribution along continental margins (e.g. Roberts et al. 2006, Hall-Spencer et al. 2007, Schroeder 2007, Wareham \& Edinger 2007, Freiwald et al. 2009). However, within the Mediterranean Sea, investigations have been more moderate and have focused mostly on CWC distributions within the central and eastern basins (e.g. Tursi et al. 2004, Taviani et al. 2005a,b, Freiwald et al. 2009). CWC distribution in the northwestern basin is poorly described in the literature; a general description of the white coral biocoenosis from Pérès \& Picard (1964) and a description by Reyss (1971) of the benthic macrofauna communities from the Cap de Creus and Lacaze-Duthiers canyons, comprise the only published investigative data.

Little quantitative information is available on the spatial distribution patterns of CWCs (but see Mortensen \& Buhl-Mortensen 2004, Parrish 2007) at large $(\mathrm{km})$, middle (100s of m) and small (m) spatial extents (term used after Dungan et al. 2002 definition). A major difficulty in acquiring information on CWC distribution 
has historically been the absence of appropriate technology to sample and survey at the depths at which they are commonly found (Gage \& Bett 2005). In recent years, improvements in remotely operated vehicle (ROV) and manned submersible design and surveying techniques have provided scientists with the opportunity to carry out accurate, quantitative in situ investigations of CWC distribution, as well as demographic studies of major species. Appropriate analytical methods for assessing spatial patterns in natural marine communities are generally undeveloped, with few exceptions (but see Yoshioka \& Yoshioka 1989). Statistical methods developed and applied previously in the field of terrestrial plant ecology could potentially be applicable for assessment of benthic species distribution (Dale 1979, 1999). Compared to facies and faunal analysis, spatial statistics permit a multi-scale quantification of species distribution patterns (such as the degree of aggregation, scale of any observable distribution patterns, patch and gap sizes, etc.). Spatial patterns in the abundance of a species are the result of past processes (e.g. reproduction, feeding, inter- and intraspecific interactions) and play a major role in determining future processes (Dale 1999).

Species distribution patterns are not exclusively determined by 'natural' factors. Progressively, human influence is playing a role in shaping marine benthic populations and communities. CWC communities have been impacted by bottom trawling (e.g. Hall-Spencer et al. 2002, 2007, Le Goff-Vitry \& Rogers 2005, Mortensen et al. 2005, Waller \& Tyler 2005, Edinger et al. 2007), with other fishing methods and gears (such as those used in benthic long-line fishing) also of concern (Lumsden et al. 2007).

In the present study we aim to improve the level of knowledge of CWC distribution within the northwestern Mediterranean by presenting the findings of an investigation into the occurrence and densities of $3 \mathrm{CWC}$ species (Madrepora oculata, Lophelia pertusa and Dendrophyllia cornigera) within a submarine canyon in the region. Additionally, we assessed spatial distribution patterns in M. oculata abundance within the canyon using spatial statistics. We also investigated the level of potential anthropogenic impact on CWC communities within the canyon by quantifying the amount of benthic long-line fishing gear and other anthropogenic material observed within the canyon. These data can be used to aid the decision-making process when deciding whether or not to establish marine protected areas in the canyon in the future. To assess these CWC distributions, we worked with ROVs and the manned submersible JAGO (Leibniz Institute of Marine Sciences [IFM-GEOMAR], Christian-Albrechts Universität, Kiel), and applied spatial statistic tools to achieve reliable quantitative data.

\section{MATERIALS AND METHODS}

Research area. The survey was conducted in the Cap de Creus canyon (northwestern Mediterranean), the most westerly of the Gulf of Lions submarine canyon system (Fig. 1) and a bathymetrically complex region with significant sediment input from the Rhone and many other small rivers. The canyon axis has a northwest to southeast orientation incising on the continental shelf with maximal depths reaching $2200 \mathrm{~m}$. The preferential direction of the coastal currents and the narrowing of the shelf towards the west results in the majority of off-shelf sediment transport on this margin running through the Cap de Creus canyon. Sediment fluxes observed in this canyon are much higher than in the eastern and central Mediterranean submarine canyons (Palanques et al. 2006). Additionally, the Cap de Creus canyon is more frequently affected by periodic arrivals of dense shelf water cascades, an oceanographic phenomenon occurring each winter in the Gulf of Lions (Durrieu de Madron et al. 2005), which make the Cap de Creus canyon head a unique environment in the northwestern Mediterranean. This oceanographic phenomenon results in rapid drops in temperature at depth. Commonly, a drop of 2 to $3^{\circ} \mathrm{C}$ occurs over a few days; for example, during winter 2003-2004 in the Cap de Creus canyon, bottom temperatures varied from maximal peaks of $15.5^{\circ} \mathrm{C}$ down to minimal values of $11.6^{\circ} \mathrm{C}$, with an average of $13.4^{\circ} \mathrm{C}$ (Palanques et al. 2006). Through these cascading events, shelf waters carrying large quantities of dissolved and particulate organic matter are rapidly advected 100s of m downward, with these cascades acting as a significant natural carbon sequestration and deep-sea ecosystem fuelling mechanism (Canals et al. 2006). This high throughput of organic material along the Cap de Creus canyon is thought to be essential for the maintenance of its associated deep-sea ecosystems and the high local biodiversity (Canals et al. 2009).

The multibeam bathymetry conducted by Fugro Engineers, AOA Geophysics and the University of Barcelona (see Lastras et al. 2007 for details) showed morphological complexity of the canyon, particularly the striking differences between the northern and southern canyon flanks (Fig. 2). The northern flank displays a smooth morphology, with rounded gullies and scars, suggesting that in recent years a depositional regime has prevailed in this sector. Sediment accumulation rates recorded from the northern flank reach values up to $1.5 \mathrm{~mm} \mathrm{yr}^{-1}$, probably due to advection via nepheloid layer transport controlled by regional southward currents (DeGeest et al. 2008). In contrast, the broad areas with hardrock outcrops, step walls and erosive morphological features that are evident on the southern flank of the Cap de Creus canyon 


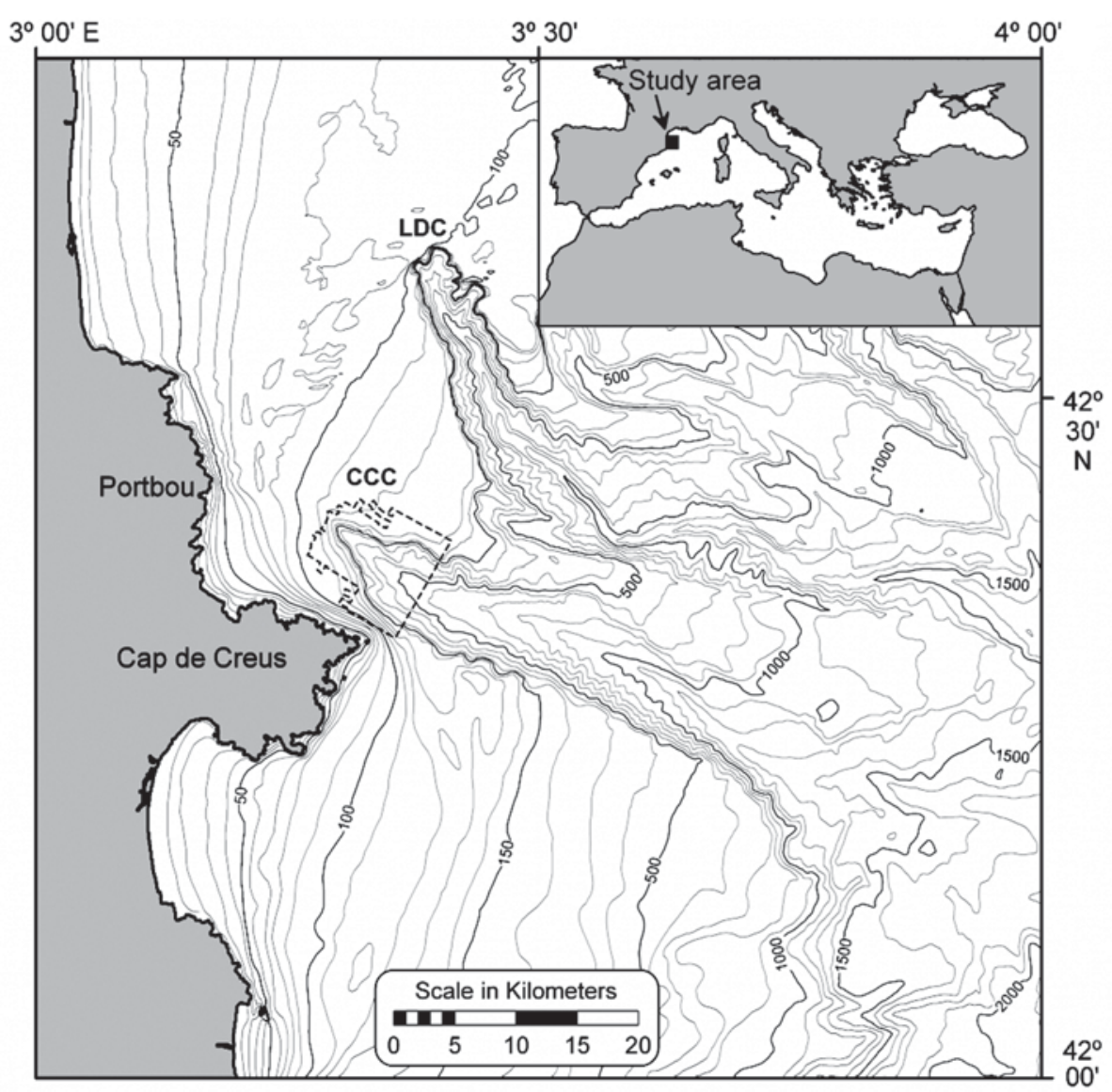

Fig. 1. Bathymetric map and location of the study area in the western sector of the Gulf of Lions, showing the Lacaze-Duthiers canyon (LDC) and the Cap de Creus canyon (CCC). The area delimited with a dashed line at the head of the CCC corresponds to coverage of the multibeam bathymetry illustrated in Fig. 2

indicate an ongoing, predominantly erosive regime (Puig et al. 2008). Accumulation rates in this area are very low and very coarse sands have been collected along the shelf edge and upper canyon rim (DeGeest et al. 2008). The main cause of the contrast in flank morphology is likely to be the varying hydrodynamic situation in the area, with the strong bottom currents and high suspended sediment loads associated with the cascading events entering the canyon preferentially via the southern flank (Puig et al. 2008).

Video surveys. Sampling was conducted in October 2005, July 2006 and September 2007 by video survey (see Table 1) from the RV 'García del Cid'. The first 2 survey campaigns (October 2005 and July 2006) were conducted by ROVs, a Falcon Sea Eye and Phantom $\mathrm{HD} 2+2$, both rated to $300 \mathrm{~m}$ water depth and equipped with colour video cameras (700 horizontal lines resolution). The third survey campaign (September 2007) was conducted by the manned submersible JAGO (400 m operation depth, cruising speed 1 knot, equipped with CTD, manipulator and 1080 horizontal lines resolution colour video camera). Positioning of the
JAGO transects was achieved using the LinkQuest TrackLink 1500 HA system and the transponder TN 1510B. The multibeam bathymetry data was used to locate the transects, with the aim of surveying hard bottom areas as far as possible. Throughout the dives, a pair of parallel laser beams mounted $50 \mathrm{~cm}$ apart allowed determination of a $1.5 \mathrm{~m}$ wide region of the seabed. This $1.5 \mathrm{~m}$ width was used to produce $1.5 \mathrm{~m}$ wide transects covering each dive, within which the densities of the 3 target species could be assessed.

A total of 22 video surveys were conducted (see Table 1), 12 with ROV and 10 with JAGO; all were carried out in the upper canyon area. The video durations produced during the ROV dives varied between 2 and $5 \mathrm{~h}$, covering a seabed distance of $\sim 500$ to $5000 \mathrm{~m}$. JAGO dives were shorter, with 2 to $4 \mathrm{~h}$ of video produced for each survey transect covering traverses of $\sim 500$ and $1500 \mathrm{~m}$. The dives carried out by ROV were recorded on digital video tapes, whereas high-definition video tapes were used to record the JAGO video data. All video material was transferred from tapes to hard disk prior to analysis. 


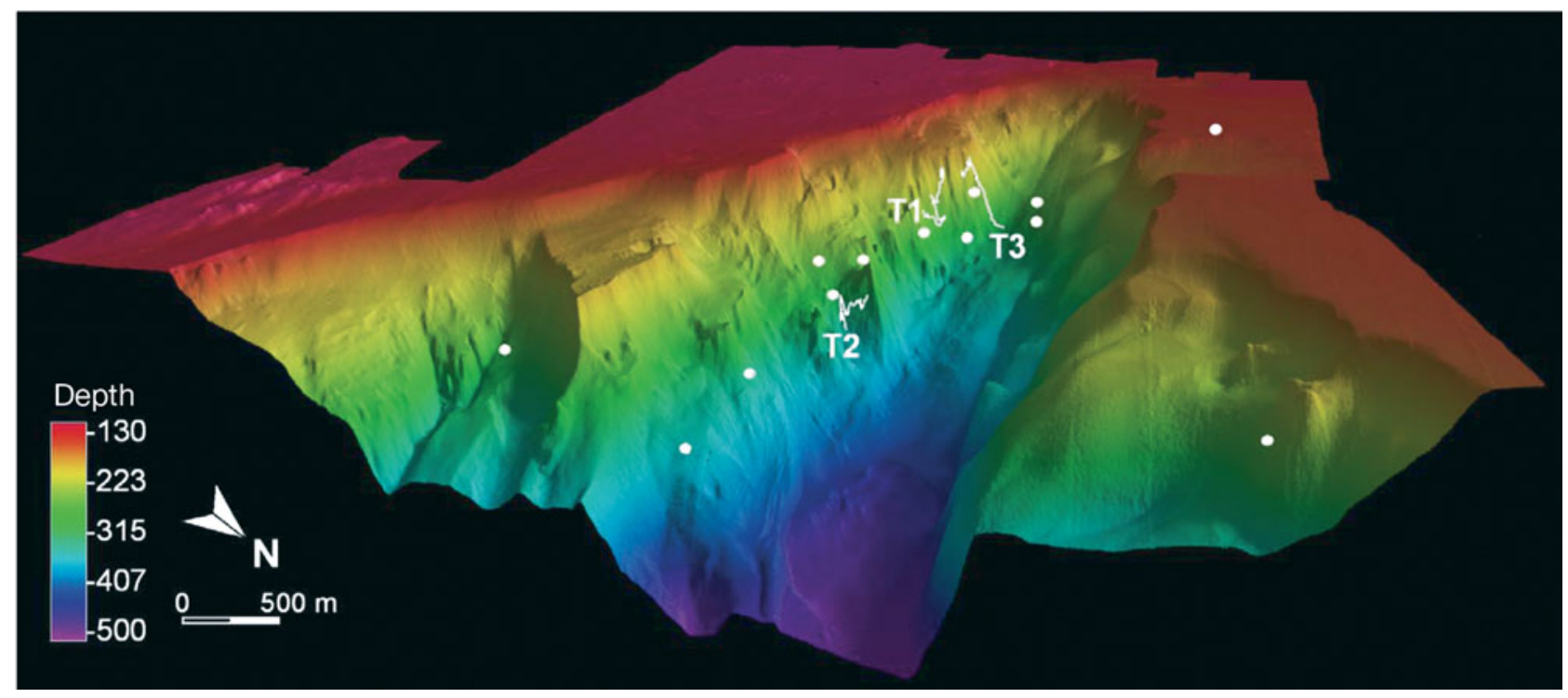

Fig. 2. Three-dimensional bathymetry of the Cap de Creus canyon (CCC) head illustrating the location of cold-water corals (white dots) in the CCC during the 3 conducted ROV (2) and JAGO (1) surveys (October 2005, July 2006 and September 2007), and the statistically analyzed JAGO video tracks (T1, T2 and T3) in the southern canyon flank

Video analysis. The video analysis was carried out with Final Cut software (Apple). Occurrence of the 3 CWC species (Madrepora oculata, Lophelia pertusa and Dendrophyllia cornigera) in the canyon was investigated by logging the locations of corals recorded on each of the video transects (from ROVs and JAGO).

Densities (colonies $\mathrm{m}^{-2}$ ) of these species were quantified through a detailed analysis of 3 (T1, T2 and T3) video transects (see Table 1, Fig. 2) recorded with the manned submersible JAGO. The initial phase of video analysis consisted of 2 stages. Firstly, during the JAGO dives the submarine would pause for either sample collection or to photograph fauna in detail-these pauses were eliminated from the transects prior to processing. Secondly, the JAGO data contained areas of poor quality data, where visibility was poor mainly due to sediment resuspension or distance from the seabed; these sections of video were also removed prior to analysis. Useful video sequences comprised a total distance of $1543 \mathrm{~m}$. All colonies of the target species appearing within the central $1.5 \mathrm{~m}$ of the video transect data were recorded.

Three different substrate types (soft sediment, rocky boulders and hardrock outcrops) were identified along each transect. Dominant substrate type was logged throughout each transect, with a substrate being considered dominant when covering $>50 \%$ of the transect width.

Anthropogenic impact was similarly logged, with occurrences of fishing gear or other man-made detritus logged throughout each video transect.

Statistical analyses. Data were analyzed by applying spatial statistics with the PASSaGE 2.0 software pack- age (Rosenberg 2008). Species distribution along the transects was displayed in density plots. Significance of deviation from a random distribution (after Lincoln et al. 1982) was analyzed with the 1-dimensional version of Ripley's K-function, plotted as L-function: $\mathrm{L}(t)=$ $t-\mathrm{K}(t) / 2$ (Ripley 1976, 1981, Haase 1995, Haase et al. 1996, Fortin \& Dale 2005). In Ripley's K-function, the number of neighboring colonies within a distance $(t)$ of each coral colony is counted; for colonies located near the transect border, an edge correction was applied (Fortin \& Dale 2005). To test the null hypothesis that there was a complete spatial randomness in coral distributions along the transects, a number of randomised transects were generated for comparison. These random transects were generated by repositioning all the observed colonies randomly along each transect. For statistical significance (95\% CI), the values of the statistic (Ripley's K-function) at the limit of $2.5 \%$ of the tails of 99 of these randomizations were used. Should the sample statistic be found within the bounds of the confidence interval at any point, then the null hypothesis could not be rejected. A significantly positive deviated sample statistic indicates a regular (after Lincoln et al. 1982) distribution, whereas a significant negative deviation suggests a contagious (after Lincoln et al. 1982) distribution pattern (Fortin \& Dale 2005). To determine the scale of the spatial pattern, three-term local quadrat variance (3TLQV) was calculated (Hill 1973, Dale 1999). Each transect was transformed into a grid of contiguous quadrats $(1 \times 1.5 \mathrm{~m})$ and species density inside each quadrat was calculated. The 3TLQV examines the average of squared differences 
among trios of adjacent block size, by subtracting twice the total of the middle block from the sum of the 2 that surround it. The resulting variance is plotted as a function of block size and peaks are indicative of pattern at that scale (Dale 1999). To identify the more frequent average smaller phase (patch or gap) sizes of the pattern, the two-term form of the new local variance (NLV) was used. As with the 3TQLV, this statistic is applied to a grid of contiguous quadrats obtained from each transect, and peaks in the plot of variance as a function of block size are interpreted as average patch or gap sizes (Galiano 1982, Dale 1999). For a correct interpretation of the results, Ludwig \& Reynolds (1988) suggest that 3TLQV and NLV should not be interpreted for block sizes $>10 \%$ of the transect length in order to maintain reasonable precision (Dale 1999). This limit was applied in this work.

Spatial statistics assume homogeneity of the study area (Ripley 1981, Dale 1999). In the survey region, seabed topography and composition were not homogeneous; nevertheless, we performed the statistical analysis over the entire transect area in order to quantify a selection of the characteristics of the spatial distribution pattern of Madrepora oculata colonies (aggregation degree, scale of the pattern, patch and gap sizes). By additionally logging substrate type across each transect, we were able to determine whether any $M$. oculata distribution patterns made evident by the statistical analysis were related to substrate change. On a more local scale, regions of the analysed transects with homogenous substrate were analysed in detail using the same statistical methods. The aim of this focused study was to assess whether or not, at the local scale, factors other than substrate type (e.g. hydrography, biotic interactions) could play a role in coral distribution patterns. Three $\sim 75 \mathrm{~m}$ long transect sections were analysed at this local scale (T1: 428 to $550 \mathrm{~m}$; T2: 84 to $160 \mathrm{~m}$; T3: 205 to $267 \mathrm{~m}$ ).

The scale of association between Madrepora oculata colonies and benthic long-line fishing gears was assessed using the three-term local quadrat covariance (3TLQC) method, which calculated variance as a function of block size for $M$. oculata (Var A) and benthic long-line fishing gears (Var B), and for their combined densities (Var A+B), where Cov = Var A+B - Var A Var B (Kershaw 1960, Dale 1999). Positions of peaks, whether positive or negative, in produced covariance graphs as a function of block size indicated the scale of any positive or negative association between the coral and the fishing gear (Dale 1999, Fortin \& Dale 2005).

\section{RESULTS}

Occurrence of CWCs was detected at 15 (68\%) of the 22 surveyed locations. Most of these stations were located in the southern flank of the canyon between approximately 180 to $300 \mathrm{~m}$ depth (Table 1, Fig. 2).

A total of 528 colonies were recorded in the 3 JAGO transects analyzed (T1, T2 and T3). The most frequent species in all transects was Madrepora oculata, which represented $93.7 \%$ of total CWC colonies. Lophelia per-

Table 1. Location of transects (ROV and submersible JAGO) in the Cap de Creus canyon during the 3 surveys. Analysed JAGO transects (T1, T2 and T3) are shaded

\begin{tabular}{|c|c|c|c|c|c|}
\hline Date & Vehicle & \multicolumn{2}{|c|}{ Position } & $\begin{array}{c}\text { Depth } \\
\text { (m, start-end) }\end{array}$ & $\begin{array}{c}\text { Coral } \\
\text { occurrence }\end{array}$ \\
\hline \multirow[t]{2}{*}{ 07/10/2005 } & FALCON Sea Eye (ROV) & $42^{\circ} 22.82 \mathrm{~N}, 3^{\circ} 17.60 \mathrm{E}$ & $42^{\circ} 22.82 \mathrm{~N}, 3^{\circ} 17.60 \mathrm{E}$ & $106-105$ & - \\
\hline & & $42^{\circ} 23.52 \mathrm{~N}, 3^{\circ} 18.77 \mathrm{E}$ & $42^{\circ} 23.26 \mathrm{~N}, 3^{\circ} 18.70 \mathrm{E}$ & $193-142$ & - \\
\hline \multirow[t]{3}{*}{ 08/10/2005 } & & $42^{\circ} 20.67 \mathrm{~N}, 3^{\circ} 20.86 \mathrm{E}$ & $42^{\circ} 20.84 \mathrm{~N}, 3^{\circ} 19.89 \mathrm{E}$ & $202-133$ & + \\
\hline & & $42^{\circ} 18.53 \mathrm{~N}, 3^{\circ} 23.60 \mathrm{E}$ & $42^{\circ} 18.68 \mathrm{~N}, 3^{\circ} 23.94 \mathrm{E}$ & $115-119$ & - \\
\hline & & $42^{\circ} 18.72 \mathrm{~N}, 3^{\circ} 25.85 \mathrm{E}$ & $42^{\circ} 18.35 \mathrm{~N}, 3^{\circ} 25.54 \mathrm{E}$ & $197-136$ & - \\
\hline 09/10/2005 & & $42^{\circ} 22.84 \mathrm{~N}, 3^{\circ} 19.62 \mathrm{E}$ & $42^{\circ} 23.59 \mathrm{~N}, 3^{\circ} 18.76 \mathrm{E}$ & $156-218$ & + \\
\hline $11 / 07 / 2006$ & Phantom HD2+2 (ROV) & $42^{\circ} 21.76 \mathrm{~N}, 3^{\circ} 20.54 \mathrm{E}$ & $42^{\circ} 22.62 \mathrm{~N}, 3^{\circ} 19.65 \mathrm{E}$ & $254-171$ & + \\
\hline $12 / 07 / 2006$ & & $42^{\circ} 23.01 \mathrm{~N}, 3^{\circ} 19.15 \mathrm{E}$ & $42^{\circ} 23.41 \mathrm{~N}, 3^{\circ} 18.86 \mathrm{E}$ & $249-251$ & + \\
\hline $13 / 07 / 2006$ & & $42^{\circ} 23.10 \mathrm{~N}, 3^{\circ} 19.15 \mathrm{E}$ & $42^{\circ} 23.26 \mathrm{~N}, 3^{\circ} 18.88 \mathrm{E}$ & $224-208$ & + \\
\hline \multirow[t]{2}{*}{$14 / 07 / 2006$} & & $42^{\circ} 23.36 \mathrm{~N}, 3^{\circ} 22.29 \mathrm{E}$ & $42^{\circ} 23.49 \mathrm{~N}, 3^{\circ} 21.82 \mathrm{E}$ & $234-184$ & + \\
\hline & & $42^{\circ} 23.21 \mathrm{~N}, 3^{\circ} 23.29 \mathrm{E}$ & $42^{\circ} 23.21 \mathrm{~N}, 3^{\circ} 22.90 \mathrm{E}$ & $205-212$ & + \\
\hline $15 / 07 / 2006$ & & $42^{\circ} 21.76 \mathrm{~N}, 3^{\circ} 20.54 \mathrm{E}$ & $42^{\circ} 22.62 \mathrm{~N}, 3^{\circ} 19.65 \mathrm{E}$ & $220-220$ & + \\
\hline 08/09/2007 & JAGO (manned submersible) & $42^{\circ} 23.10 \mathrm{~N}, 3^{\circ} 19.14 \mathrm{E}$ & $42^{\circ} 23.18 \mathrm{~N}, 3^{\circ} 18.87 \mathrm{E}$ & $220-150$ & - \\
\hline \multirow{2}{*}{ 09/09/2007 } & & $42^{\circ} 23.38 \mathrm{~N}, 3^{\circ} 18.84 \mathrm{E}$ & $42^{\circ} 23.39 \mathrm{~N}, 3^{\circ} 18.83 \mathrm{E}$ & $186-190$ & + \\
\hline & & $42^{\circ} 21.98 \mathrm{~N}, 3^{\circ} 21.47 \mathrm{E}$ & $42^{\circ} 20.97 \mathrm{~N}, 3^{\circ} 21.58 \mathrm{E}$ & $390-376$ & - \\
\hline $10 / 09 / 2007$ & & $42^{\circ} 23.21 \mathrm{~N}, 3^{\circ} 19.01 \mathrm{E}$ & $42^{\circ} 23.33 \mathrm{~N}, 3^{\circ} 18.84 \mathrm{E}$ & $207-156$ & $+(\mathrm{T} 1)$ \\
\hline $12 / 09 / 2007$ & & $42^{\circ} 23.13 \mathrm{~N}, 3^{\circ} 19.20 \mathrm{E}$ & $42^{\circ} 23.20 \mathrm{~N}, 3^{\circ} 19.26 \mathrm{E}$ & $252-260$ & + \\
\hline $13 / 09 / 2007$ & & $42^{\circ} 22.71 \mathrm{~N}, 3^{\circ} 19.75 \mathrm{E}$ & $42^{\circ} 22.79 \mathrm{~N}, 3^{\circ} 19.73 \mathrm{E}$ & $306-285$ & $+(\mathrm{T} 2)$ \\
\hline $14 / 09 / 2007$ & & $42^{\circ} 21.41 \mathrm{~N}, 3^{\circ} 20.03 \mathrm{E}$ & $42^{\circ} 21.39 \mathrm{~N}, 3^{\circ} 20.04 \mathrm{E}$ & $235-235$ & + \\
\hline \multirow[t]{2}{*}{$15 / 09 / 2007$} & & $42^{\circ} 22.14 \mathrm{~N}, 3^{\circ} 20.28 \mathrm{E}$ & $42^{\circ} 22.27 \mathrm{~N}, 3^{\circ} 20.20 \mathrm{E}$ & $295-256$ & $+(\mathrm{T} 3)$ \\
\hline & & $42^{\circ} 23.60 \mathrm{~N}, 3^{\circ} 18.90 \mathrm{E}$ & $42^{\circ} 23.43 \mathrm{~N}, 3^{\circ} 18.79 \mathrm{E}$ & $285-150$ & + \\
\hline $16 / 09 / 2007$ & & $42^{\circ} 24.04 \mathrm{~N}, 3^{\circ} 19.48 \mathrm{E}$ & $42^{\circ} 24.08 \mathrm{~N}, 3^{\circ} 19.33 \mathrm{E}$ & $125-160$ & - \\
\hline
\end{tabular}



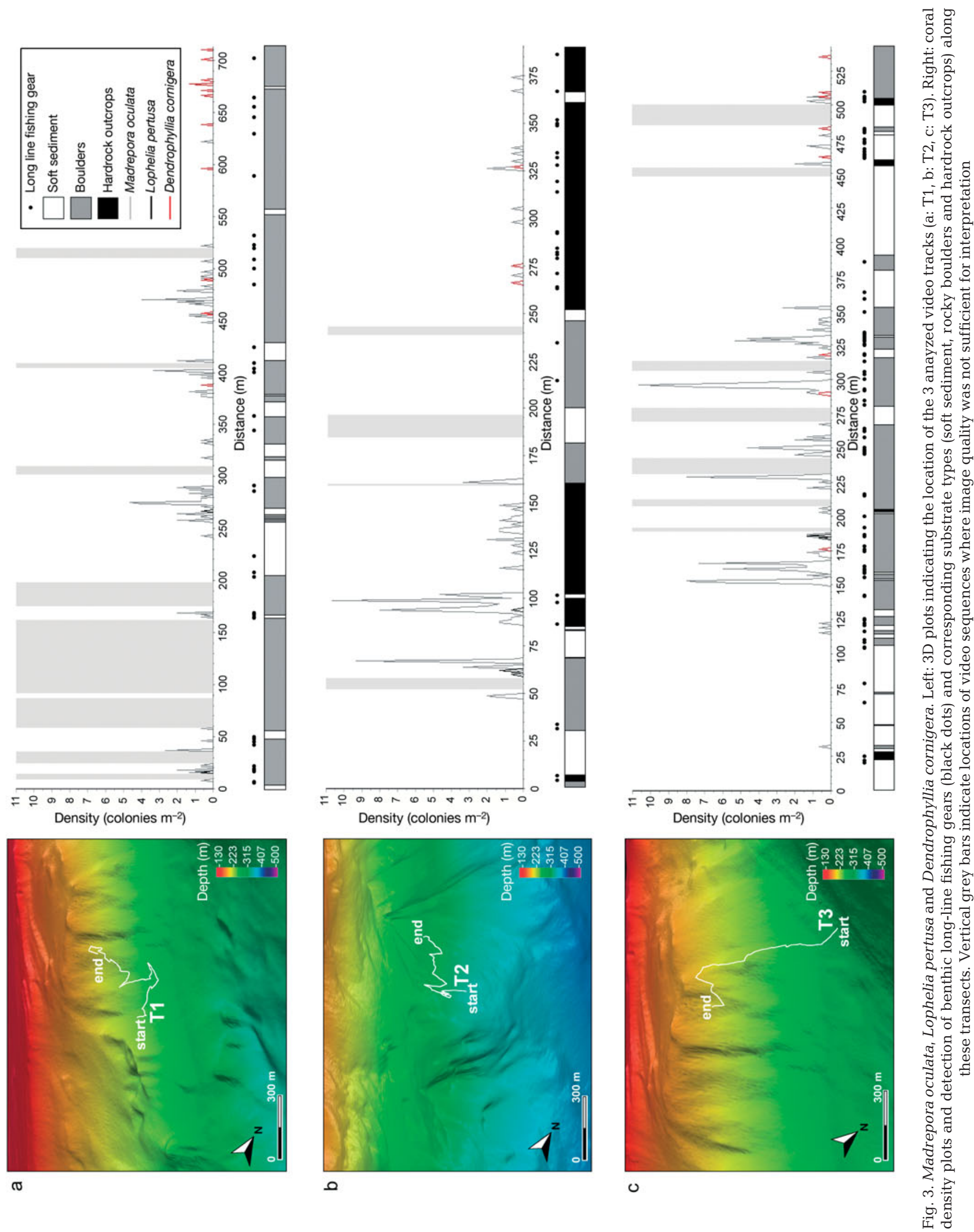

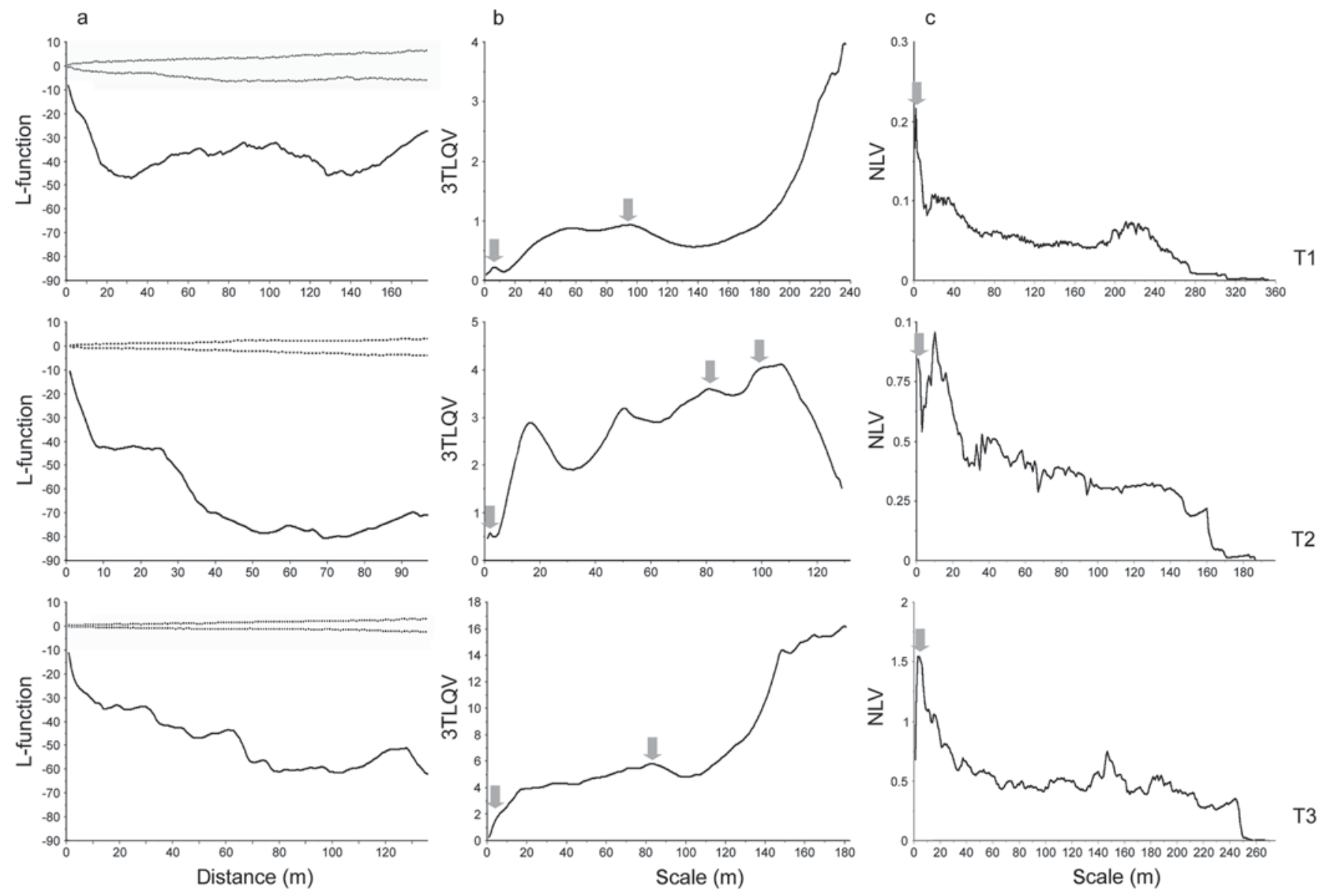

Fig. 4. Madrepora oculata. Spatial statistics for transects T1, T2 and T3. (a) L-function (Ripley's K); values below $95 \%$ CI (dotted lines) indicate a statistically significant contagious distribution. (b) Three-term local quadrat variance 93TLQV) as a function of scale (block size); arrows indicate the scale of the spatial pattern coincident for the 3 transects. (c) New local variance (NLV) as a function of scale (size of the smaller phase of the pattern); arrows indicate the most frequent patch sizes for all transects

tusa $(1.7 \%$ total CWC colonies) and Dendrophyllia cornigera (4.6\% total CWC colonies) were less common (Table 2). Presence of M. oculata was 1 order of magnitude higher in areas with hard substrate bottom types, i.e. boulders $\left(0.44 \pm 0.33\right.$ [SD] colonies $\left.\mathrm{m}^{-2}\right)$ and hardrock outcrops $\left(0.41 \pm 0.40\right.$ colonies $\left.\mathrm{m}^{-2}\right)$, than in regions with soft bottom substrates $\left(0.07 \pm 0.09\right.$ colonies $\left.\mathrm{m}^{-2}\right)$. L. pertusa was only observed on boulders $(0.01 \pm 0.01$ colonies $\mathrm{m}^{-2}$ ). D. cornigera, although more commonly found on boulders $\left(0.02 \pm 0.01\right.$ colonies $\left.\mathrm{m}^{-2}\right)$, was also observed on hardrock outcrops $\left(0.005 \pm 0.01\right.$ colonies $\left.\mathrm{m}^{-2}\right)$.

Although densities of Madrepora oculata, Lophelia pertusa and Dendrophyllia cornigera varied between species, the densities for each species did not vary much between transects (Table 2, Fig. 3). M. oculata was the CWC present in highest density across the 3 transect regions, varying from $0.11 \pm 0.44$ to $0.30 \pm$ 0.44 colonies $\mathrm{m}^{-2}$, with maximal values of 10.67 colonies $\mathrm{m}^{-2}$. D. cornigera density was much lower than M. oculata across all transects, varying only moder- ately between transects, from $0.01 \pm 0.09$ to $0.01 \pm$ 0.67 colonies $\mathrm{m}^{-2}$, with a maximal value of 1.33 colonies $\mathrm{m}^{-2}$. L. pertusa was observed to have the lowest and most variable density between transects, from $0.002 \pm 0.035$ to $0.01 \pm 0.08$ colonies $\mathrm{m}^{-2}$, with a maximal value of 1.33 colonies $\mathrm{m}^{-2}$. The low densities of $L$. pertusa and D. cornigera (Table 2, Fig. 3) rendered the spatial statistics inapplicable; thus a detailed analysis on the aggregation degree and spatial patterns was conducted only for $M$. oculata.

The distribution of Madrepora oculata was significantly different from complete spatial randomness in all transects and at all scales. The significant negative deviation from randomness, after applying Ripley's Kfunction, indicated a contagious distribution of $M$. oculata colonies (Fig. 4a).

The 3TLQV analysis showed several scales in the spatial pattern of Madrepora oculata colonies (Fig. 4b). Some scales of spatial pattern were detected in all transects $(<5 \mathrm{~m}$ and $\sim 80$ to $90 \mathrm{~m})$. In transects $\mathrm{T} 2$ and 

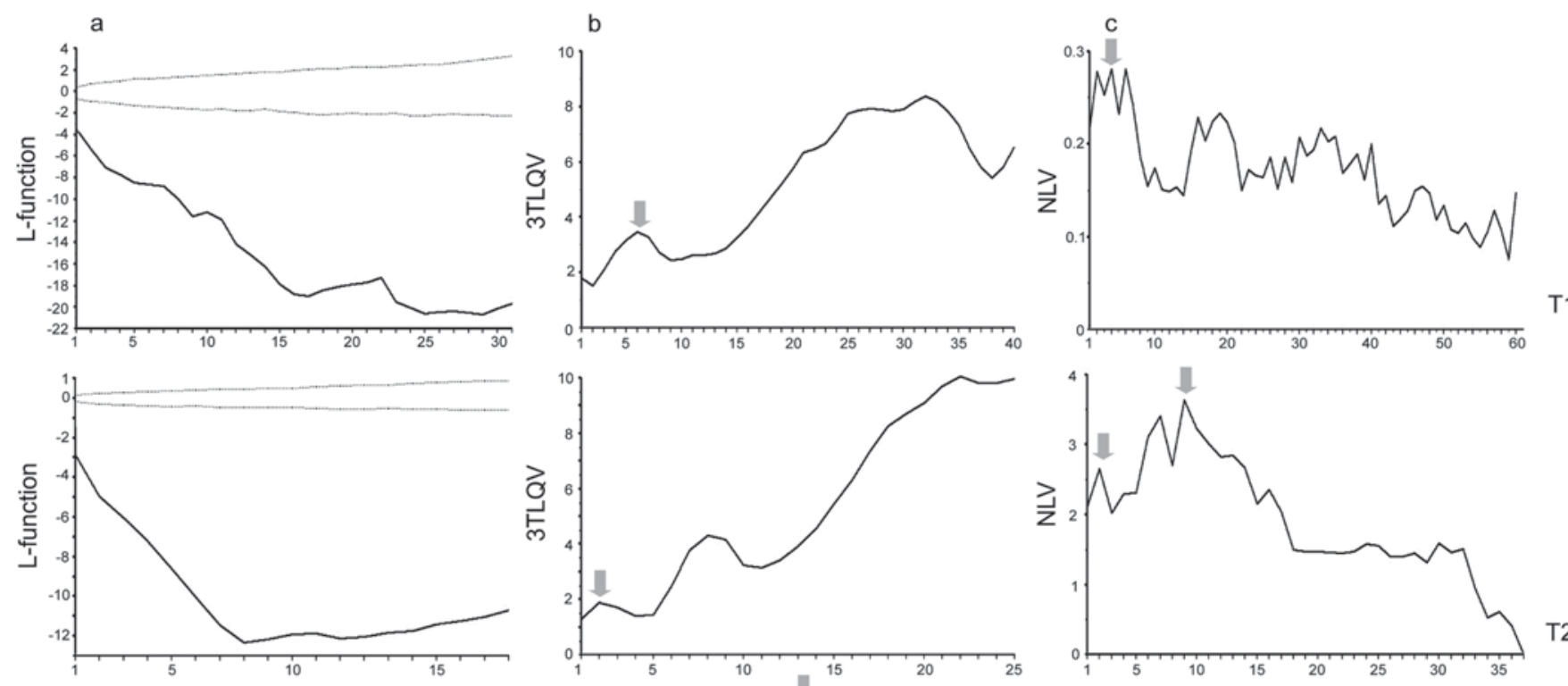

T2
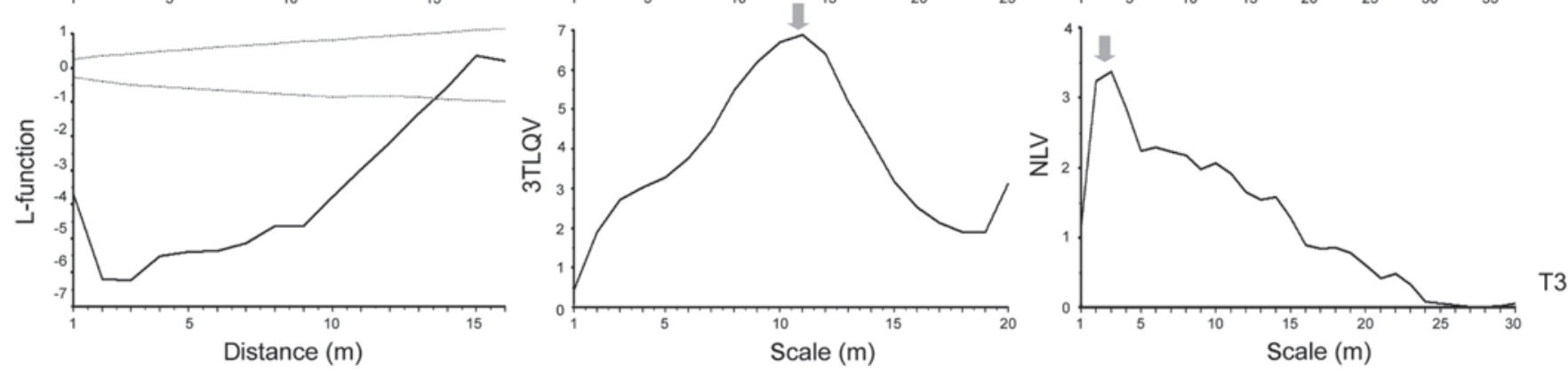

Fig. 5. Madrepora oculata. Spatial statistics across selected sections of transects with homogenous substrate: T1 (428 to $550 \mathrm{~m}$ ), T2 (84 to $160 \mathrm{~m}$ ) and T3 (205 to $267 \mathrm{~m}$ ). (a) L-function (Ripley's K), scale represents fragment distance; values below $95 \%$ CI (dotted lines) indicate a statistically significant contagious distribution. (b) Three-term local quadrat variance (3TLQV) as a function of scale (block size of the aggregation pattern); arrows: the main aggregation levels for each transect. (c) New local variance (NLV) as a function of scale (size of the smaller phase of the pattern); arrows: the most frequent patch sizes for each transect

T3 intermediate scales (at $\sim 20 \mathrm{~m}$ and $\sim 100 \mathrm{~m}$ ) were detected, whereas in transects T1 and T2 a further pattern scale was found at $\sim 50 \mathrm{~m}$ (Fig. 4b).

In the 3 transects there was a clear sharp peak in the NLV plot at around 2 to $5 \mathrm{~m}$, indicating that the most common patches were small (Fig. 4c). However, all transects showed secondary small peaks which corre-

Table 2. Madrepora oculata, Lophelia pertusa and Dendrophyllia cornigera. Mean \pm SD (maximal) density for the 3 studied species. T: transect

\begin{tabular}{|cccc|}
\hline & \multicolumn{3}{c|}{ Density $\left(\right.$ colonies $\left.\mathrm{m}^{-2}\right)$} \\
& $\mathrm{T} 1$ & $\mathrm{~T} 2$ & $\mathrm{~T} 3$ \\
\hline M. oculata & $0.11 \pm 0.44$ & $0.23 \pm 0.99$ & $0.30 \pm 1.14$ \\
& $(4.67)$ & $(10.67)$ & $(10.67)$ \\
L. pertusa & $0.002 \pm 0.035$ & $0.01 \pm 0.08$ & $0.004 \pm 0.06$ \\
& $(0.67)$ & $(1.33)$ & $(1.33)$ \\
D. cornigera & $0.01 \pm 0.09$ & $0.01 \pm 0.06$ & $0.01 \pm 0.09$ \\
& $(1.33)$ & $(0.67)$ & $(0.67)$ \\
\hline
\end{tabular}

sponded to subsequently defined patch sizes, indicating a range of patch sizes in this species.

The distribution of Madrepora oculata was also found to be contagious in the small-scale analysis plots representing the homogenous substrate regions of each transect (Fig. 5a). The 3TLQV analysis showed several small scales in the spatial pattern of $M$. oculata colonies (between 2 and $11 \mathrm{~m}$ ) (Fig. 5b), with some of these scales being coincident with the smallest scales identified in the whole transects (Fig. 4b). Furthermore, the results obtained for the NLV analysis of each of these small homogenous regions was also coincident with the results generated for each whole transect, i.e. the most dense patch sizes are also small (between 2 and 10 m) (Fig. 5c).

A total of 197 benthic long-line fishing gears were recorded across the 3 transects, with an average of $0.06,0.09$ and 0.22 lines $\mathrm{m}^{-1}$ at each transect, respectively. The 3TLQC plots showing spatial covariation in Madrepora oculata and benthic long-line fishing gear occurrence across the transects is shown in Fig. 6. At a 

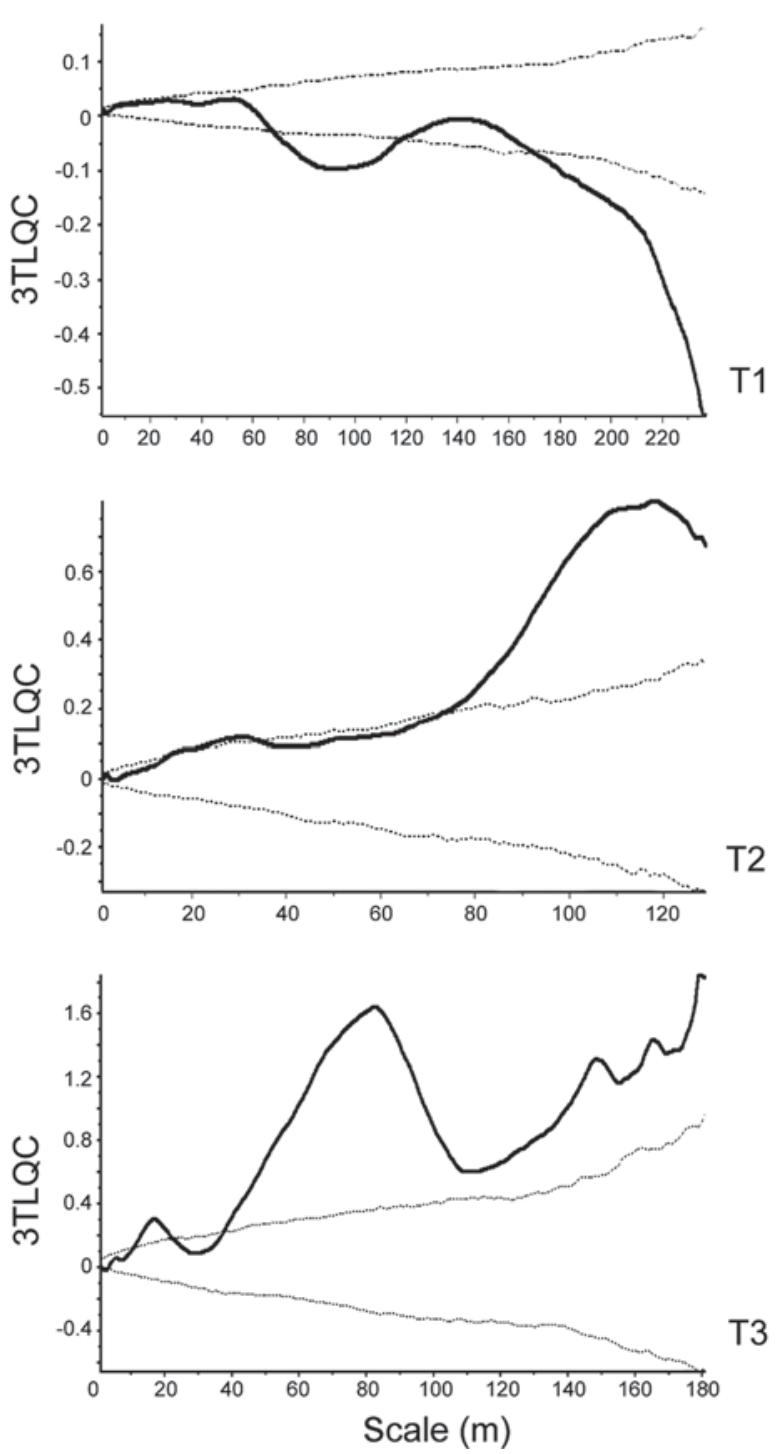

Fig. 6. Madrepora oculata. Three-term local quadrat covariance (3TLQC) for M. oculata and benthic long-line fishing gear occurrence in the 3 analysed transects (T1, T2 and T3). Values outside $95 \%$ CI (dotted lines) indicate a statistically significant spatial covariance. Scale represents the block size

scale of meters, the pattern is random across the 3 transects. At scales of $10 \mathrm{~s}$ of $\mathrm{m}$ (20 to $80 \mathrm{~m})$, the covariance is positive across transects T2 and T3 implying that at this scale, coral occurrence correlates with benthic long-line fishing gear occurrence. In contrast, transect T1 shows a negative covariance at this scale, indicating that wherever corals are present, benthic long line fishing gears are likely to be absent and vice versa.

Some other anthropogenic impacts were sporadically observed and thus counted in the analysed videos: a Roman amphora, a fragment of a fishing net and a plastic fragment.

\section{DISCUSSION}

\section{CWC occurrence in the Cap de Creus canyon}

CWCs are the most conspicuous animal group in the hard substrate regions of the Cap de Creus canyon flanks. The predominant presence of CWCs in the southern flank of the canyon is directly related to the broad areas of hardrock outcrops and steep walls. Furthermore, this side of the canyon (Fig. 2) is characterized by the arrival of recurrent dense shelf water cascades during winter (Puig et al. 2008), as described in 'Materials and methods'. Therefore, coral occurrence in this area seems to be related to: (1) the energetic current flows carrying periodically nutritive particles in suspension from the shelf environments (Canals et al. 2006) and (2) the reduced sediment accumulation rates caused by the cascading process (DeGeest et al. 2008); both aspects (hydrodynamics and/or food supply, sedimentation pressure) have been documented as determining factors in CWC occurrence in other systems (e.g. Frederiksen et al. 1992, White et al. 2005). Contrary to the erosional features of the southern flank of the canyon, the northern flank is marked by features indicating a prevailing depositional regime with high sedimentation rates (rounded gullies and smoothed scars). These high sediment accumulation rates have resulted in the scarce occurrence of rocky substrates (DeGeest et al. 2008). This is probably the cause of the scarce presence of CWCs on the northern flank. Former observations indicate that scleractinians occur in areas where the interaction between currents and topography can generate high-speed flow (e.g. Frederiksen et al. 1992, White et al. 2005, 2007, Grasmueck et al. 2006, Dorschel et al. 2007, Mienis et al. 2007), which both helps to remove excess sediment and also supply food and larvae (Grigg 1984).

Consequently, even if available substrate is one of the main determining factors of the distribution pattern of Madrepora oculata within the canyon, the current regime could play as large a role. This is more likely when the episodic cascading events, or the presence of near-inertial internal waves at the shelf edge of the Gulf of Lions (Millot \& Crépon 1981), are taken into account. Although internal waves do not contribute to the main off-shelf sediment transport through the Cap de Creus canyon (Palanques et al. 2008), this hydrographical phenomenon can periodically control the resuspension, advection and mixing of turbid shelf water into the canyon heads (Ogston et al. 2008). This resuspension of light organic matter aggregates by internal waves could provide additional food supply to corals (Frederiksen et al. 1992). 


\section{Madrepora oculata distribution pattern in the Cap de Creus canyon}

There is a clear relationship between substrate and Madrepora oculata density, with the highest $M$. oculata densities being found in regions with hard substrates (Fig. 3). The other 2 studied corals, Lophelia pertusa and Dendrophyllia cornigera, were present only in the hard substrate areas. This relationship between substrate type and CWC occurrence has been observed elsewhere (Rogers 1990, Davies et al. 2008).

Contagious distributions are common among benthic organisms and, as is found with terrestrial plants, are more common than regular distributions, with random distributions rarely found (Kershaw 1958). The contagious distribution pattern of Madrepora oculata in the Cap de Creus canyon (Figs. 4 \& 5) is probably the result of interactions between several factors (both physical and biological) with the presence of a hard substrate (boulders and outcrops), high hydrodynamic regime (both the current regime and episodic cascading events) and high nutrient delivery the most significant in determining distribution. Food supply has been observed as an important factor in influencing patch distribution in the deep sea: Grassle \& Grassle (1992) and Grassle \& Morse-Porteous (1987) argued that localized concentrations of food (such as phytodetritus pulses from surface blooms) and carcass falls are important patch food structures in the deep sea, greatly boosting food availability in areas with a low background productivity. Duineveld et al. (2004) also documented the importance of the food supply from surface waters in understanding local diversity and density in seamounts and deep coral banks.

The observed spatial distribution pattern for Madrepora oculata in the Cap de Creus canyon is unbalanced when considering the transects as a whole. Large periodic gaps in $M$. oculata dominate the 3 transects (see Fig. 3), with these gaps mainly correlating with changes in substrate. However, the spatial analysis carried out in the transect regions with homogenous substrate also present contagious $M$. oculata distribution patterns (Fig. 5). For these regions, in which substrate cannot be a factor in determining the distribution pattern, other aforementioned factors (such as current regime and food supply) are most likely responsible for the observed pattern.

After the 3TLQV and the NLV results, we identified 2 common scales within the Madrepora oculata distribution pattern across the 3 transects $(<5 \mathrm{~m}$ and $\sim 80$ to $90 \mathrm{~m}$ ) (Figs. 4b,c \& 5b,c). This observation of very similar distribution patterns across the 3 transects suggests that they are likely to be representative of the southern flanks of the Cap de Creus canyon as a whole. However, the identification of other scales of pattern in some of the transects $(15,25,150$ and 215 to 220 m) (Fig. 4b) indicates a degree of local variability.

The smallest scale of pattern found in the canyon corresponds to the smallest patch sizes of Madrepora oculata observed in the transects $(<5 \mathrm{~m})$. These small patches may be due to: (1) settlement on non-optimal substrate (e.g. on small pebbles in a soft-bottom dominant substrate), (2) patchiness of food or (3) the reproduction strategy of the species. Following the reasoning of Greig-Smith (1961), for gorgonian distributions the dominant patch size (which for $M$. oculata within the canyon is $<5 \mathrm{~m}$ ) represents the spatial scales at which the major ecological process controlling shallow-water gorgonian communities is most fully developed. In the case of the gorgonians studied by Yoshioka \& Yoshioka (1989), visual inspections of the habitat suggested that patch sizes correspond to the predominant scales of topographic elevations. Even if the topographical variation was relatively small, involving differences in relief of only a few centimetres, they observed a dramatic effect on gorgonian abundances. A similarly significant change in distribution associated with a minor change in a controlling factor could be expected for the coral species in the present study.

The convex shape of most Madrepora oculata patches (Fig. 3) indicates that the highest densities occur in the middle of each patch. This is probably related to active growth of the patches and/or outward expansion. Patches are hydrodynamically significant, reducing current flow within and surrounding the patches, thus increasing the local residence time of particles in suspension. This increased residence time allows local organisms (predominantly the CWCs in this case) longer to capture them (Gili \& Coma 1998). Another major factor in determining benthic organism patch size and enlargement rate is strategy of larval dispersal (Lissner et al. 1991). Lophelia pertusa and $M$. oculata are observed to be most commonly seasonal broadcasters, with direct release of the gametes into the water column, probably over a limited time period (Brooke \& Young 2003, Waller \& Tyler 2005). However, recent observations of the presence and survival of $L$. pertusa larvae in aquaria showed a survival time of $7 \mathrm{wk}$, but an increase in mortality after about 4 to $5 \mathrm{wk}$, prior to which settlement had not been observed ( $\mathrm{T}$. Lundälv pers. comm.). This live larval period exceeds that observed for the CWC Oculina varicosa, where 20 live days has been observed (Brooke \& Young 2003). The ecological significance of such 'long-life' larva is high, as the larvae could be transported via benthic currents to locations far from the parental colonies, allowing colonization over significant distance. Rogers (1999) pointed out that larval dispersion should play a paramount role in the degree of spread- 
ing of CWC species, as observed in the Stylasterines where the short-lived larvae (produced by both shallow- and deep-water Stylasterines) and their planulae settle close to the parent colonies (Fritchman 1974, Ostarello 1976, Brooke \& Stone 2007), determining the population structure as well as the dispersal patterns. This pattern has also been observed in several species of anthozoans (Fautin 2002). In the present study, the presence of isolated colonies (10s of $\mathrm{m}$ between) could reflect either the remains of larger colonies (after possible environmental or anthropogenic perturbations) or more recent pioneer colonies (produced sexually or asexually) entering the area. Moreover, it is known that asexual reproduction (fragmentation) is likely to play an important role in scleractinians (Highsmith 1982).

The observed gaps in Madrepora oculata coverage of areas with rocky substrate could also be the result of natural perturbations, such as corals breaking under heavy flow or excessive growth, or of anthropogenic impact. The large quantity of benthic long-line fishing gear found within the canyon indicates that the seabed is periodically exposed to dragging lines (Fig. 3). The 3TLQC analysis did not show a clear pattern in the relationship between benthic long-line fishing gear distribution on the seabed and coral density (Fig. 6); however, at a scale of $10 \mathrm{~s}$ of $\mathrm{m}$ in transects T2 and T3 there is a degree of relationship between benthic gear occurrence and coral density. This is perhaps best explained by the larger coral-covered hard substrate regions snagging the long-lines more effectively than the soft sediment or coral-free seabed areas. This entanglement is not uncommon and can be seen in Fig. $7 \mathrm{~b}, \mathrm{~d}$. In T1, however, at a scale of $10 \mathrm{~s}$ of $\mathrm{m}$, a negative correlation between corals and benthic lines can be
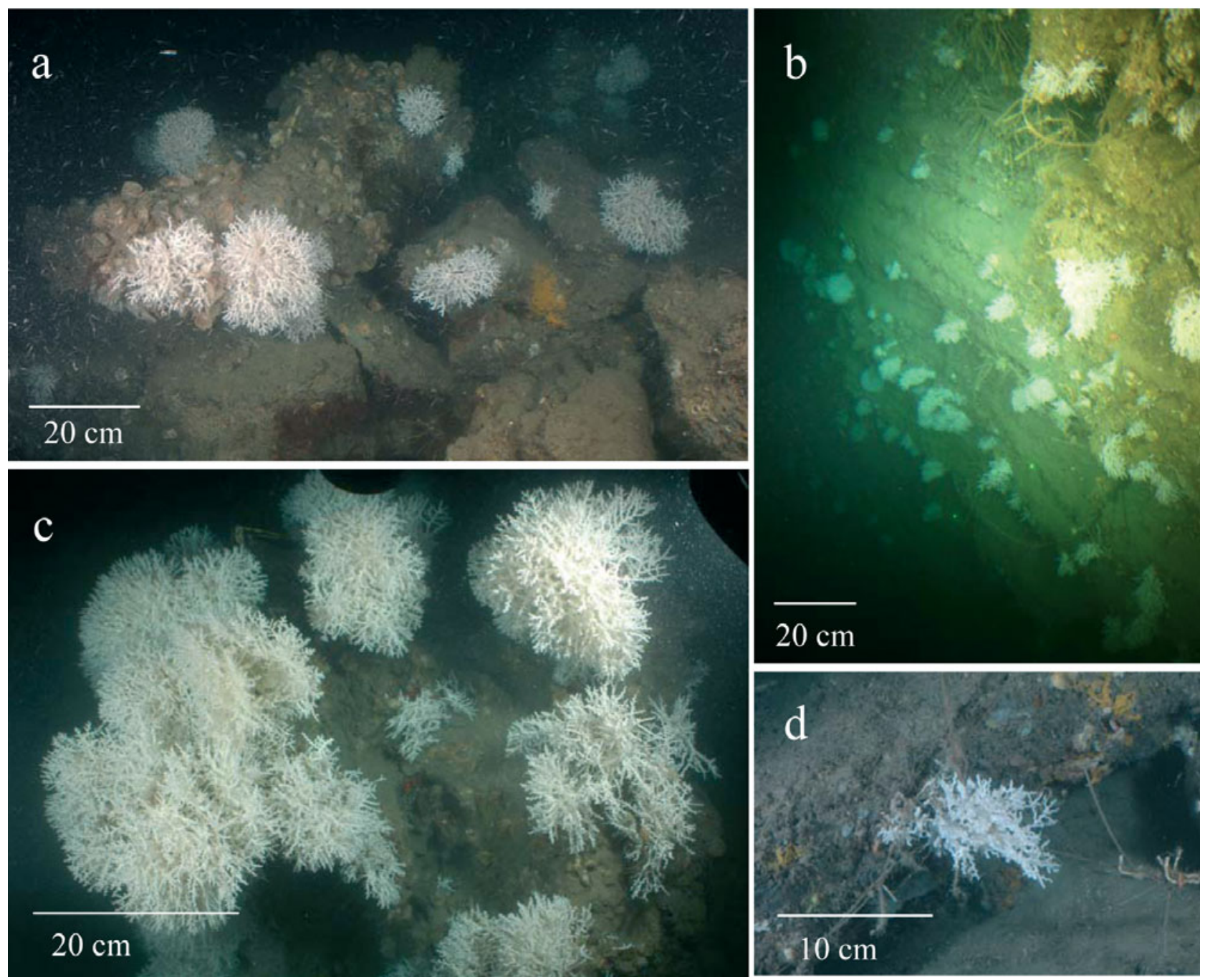

Fig. 7. Madrepora oculata. Coral colonies on the southern flank of the canyon (a) growing on boulders at $250 \mathrm{~m}$ depth; (b) on a rocky outcrop at $300 \mathrm{~m} \mathrm{depth}$; (c) dense populations on boulders at $250 \mathrm{~m}$ depth; (d) entangled in long-line fishing gear at $200 \mathrm{~m}$ depth 
seen (Fig. 6); it is therefore difficult to present any firm conclusions about the potential threat of benthic longline fishing gears to the corals in this area. However, further investigations should be carried out in more canyon locations to explore the possible relationship between coral occurrence and lost fishing equipment, particularly as this type of fishing has been observed to have a negative impact on CWC communities in other areas (Lumsden et al. 2007).

\section{CWC in the Mediterranean Sea}

Madrepora oculata is the dominant CWC in the Cap de Creus system. This is in contrast with dominances found in other better documented CWC ecosystems, such as on the NE Atlantic shelf where Lophelia pertusa is the dominant species, or the NW Atlantic where L. pertusa and Oculina varicosa are most dominant (Reed 1992, Breeze et al. 1997, Fosså et al. 2000, Gass 2002). CWC ecosystems elsewhere in the Mediterranean Sea are mostly dominated by M. oculata and $L$. pertusa (Pérès \& Picard 1964, Pérès 1982, Tursi et al. 2004, Taviani et al. 2005a, Freiwald et al. 2009); however, a dominance of $M$. oculata has been reported in some regions, such as off Thassos (Freiwald et al. 2009), Santa Maria di Leuca (Taviani et al. 2005a, Freiwald et al. 2009) and Malta (Freiwald et al. 2009).

By comparing the results of the present study with published papers on Madrepora oculata-dominated CWC banks within the Mediterranean (Tursi et al. 2004, Taviani et al. 2005a, Freiwald et al. 2009), the populations found in the southern flank of the Cap de Creus canyon seem to comprise one of the most developed M. oculata-dominated ecosystems. This is supported particularly by the density data (Table 2, Fig. 3) and photographs of some locations within the Cap de Creus canyon (Fig. 7).

The presence of Lophelia pertusa (which was first discovered alive in the Mediterranean as recently as 2000, Tursi et al. 2004) in these communities is very scarce (Table 2, Fig. 3). This is true for other CWC sites in the east and central Mediterranean (Tursi et al. 2004, Taviani et al. 2005a,b, Freiwald et al. 2009). The reasons for these low densities of $L$. pertusa in the Mediterranean (limited to some isolated colonies in the Cap de Creus canyon) is still unknown. Nevertheless, it is likely that the living white coral biocoenosis in the Mediterranean Sea consists of relicts from past flourishing times (Pérès \& Picard 1964, Pérès 1982). The most likely causes of the dramatic decrease in occurrence of Mediterranean CWCs have been attributed to the major changes in oceanographic and geologic conditions which occurred during the Holocene sea level rise (Pérès 1982, Delibrias \& Taviani 1984). During the start of the Holocene sea level rise, changes in climatic conditions produced a strong increase in Mediterranean water temperatures, modifying the environmental conditions that were present and favourable to CWCs during the last glacial maximum (Delibrias \& Taviani 1984) to those less favourable. Based on ${ }^{14} \mathrm{C}$ dating, Delibrias \& Taviani (1984) estimated that the major decline of CWC abundance in the Mediterranean Sea took place during the period ranging from 30 to $15 \mathrm{kyr}$ BP. Other researchers have suggested different dates: McCulloch et al. (2006) dated the demise of CWCs in the Mediterranean to the end of the Younger Dryas (10.5 kyr BP), which was a cool period occurring during the last sea level rise and characterized by more glacial-like conditions. At the end of the Younger Dryas, the combined effect of a rapid 6 to $8^{\circ} \mathrm{C}$ rise in ocean temperatures and high sediment influx from river discharge by glacial melt water pulses may have promoted the CWC recession (McCulloch et al. 2006).

The idea that homoeothermic conditions within the Mediterranean Sea are responsible for the general scarcity of CWC communities is given support by the documented in situ temperature tolerance limits for Lophelia pertusa, which range from 4 to $13^{\circ} \mathrm{C}$ (Freiwald 2002). This means that $L$. pertusa within the Mediterranean is living close to its upper temperature limit. In the Cap de Creus canyon, the maximal documented temperature peak recorded at $300 \mathrm{~m}$ water depth is $15.5^{\circ} \mathrm{C}$ (Palanques et al. 2006). Temperature tolerance seems to be wider for Madrepora oculata, which is able to function at temperatures up to $20^{\circ} \mathrm{C}$ (Keller \& Os'kina 2008). The low abundances of Dendrophyllia cornigera in the Cap de Creus canyon are not surprising, as this species is not reef-forming and the densities we found agree well with previous observational records in other regions (Le Danois 1948), although recent research documented that $D$. cornigera could reach high densities in some locations (Sánchez et al. 2009). However, new data showed that CWCs also existed during the Holocene in the Mediterranean Sea (Ruggeberg et al. 2008). In Wienberg et al. (2009), the authors discuss the temperature and current speed tolerances of M. oculata, L. pertusa and $D$. cornigera in the Gulf of Cadiz during the interglacial and glacial periods. They found that both $M$. oculata and $D$. cornigera coped better with temperature and flow rate changes than $L$. pertusa.

In conclusion, this new insight in the distribution of CWCs in the Cap de Creus canyon in the northwest Mediterranean, and the high densities reported in the southern flank of the canyon, will be of significant use in planning future marine protected areas and management measures in order to preserve the CWC communities in this area. 
Acknowledgements. The authors thank Fugro Survey, AOA Geophysics and the University of Barcelona for the multibeam bathymetry of the Cap de Creus canyon, M. S. Rosenberg for permission to use the PASSaGE software, the owners of the ROVs FIELAX (Bremerhaven, Germany) and INSTALSUB (Barcelona, Spain), as well as the JAGO team (J. Schauer and K. Hissmann) from IFM-GEOMAR (Kiel, Germany). This work was funded by the European Project HERMES (Goce-CT-2005-511234-I), the Spanish Project DEEP CORAL (CTM2005-07756-C02-02/MAR) and the Acciones Complementarias (CTM2005-24174-E, CTM200627063-E/MAR, CTM2007-28758-E/MAR). C.O., A.G. and C.L.I. were supported by I3P CSIC contracts. We are in debt to the crew of the RV 'García del Cid'; without their help it would not have been not possible to carry out the fieldwork. Thanks to L. Yebra and A. Purser for a comprehensive English revision of the text. The final version of the manuscript has very much improved thanks to the comments of 3 anonymous reviewers. This paper is dedicated to the memory of Frances Pagès.

\section{LITERATURE CITED}

Breeze H, Davis DS, Butler M, Kostylev V (1997) Distribution and status of deep-sea corals off Nova Scotia. Marine Issue Comm Spec Publ 1. Ecology Action Center, Halifax, Nova Scotia

Brooke S, Stone R (2007) Reproduction of deep-water hydrocorals (family Stylasteridae) from the Aleutian Islands, Alaska. Bull Mar Sci 81:519-532

Brooke S, Young C (2003) Reproductive ecology of a deepwater scleractinian coral, Oculina varicosa, from the southeast Florida shelf. Cont Shelf Res 23:847-858

Canals M, Puig P, Durrieu de Madron X, Heussner S, Palanques A, Fabrés J (2006) Flushing submarine canyons. Nature 444:354-357

Canals M, DANOVAro R, Heussner S, Lykousis V and others (2009) Cascades in Mediterranean submarine grand canyons. Oceanography 22:26-43

Dale MRT (1979) The analysis of patterns of zonation and phytosociological structure of seaweed communities. PhD thesis, Dalhousie University, Halifax, Nova Scotia

Dale MRT (1999) Basic methods for one dimension and one species. In: Spatial pattern analysis in plant ecology. Cambridge Studies in Ecology, Cambridge University Press, Cambridge

- Davies AJ, Wisshak M, Orr JC, Roberts JM (2008) Predicting suitable habitat for the cold-water coral Lophelia pertusa (Scleractinia). Deep-Sea Res Part I 55:1048-1062

DeGeest AL, Mullenbach BL, Puig P, Nittrouer CA, Drexler TM, Durrieu de Madron X, Orange DL (2008) Sediment accumulation in the western Gulf of Lions, France: the role of Cap de Creus canyon in linking shelf and slope sediment dispersal systems. Cont Shelf Res 28:2031-2047

Delibrias G, Taviani M (1984) Dating the death of Mediterranean deep-sea scleractinian corals. Mar Geol 62:175-180

Dorschel B, Hebbeln D, Foubert A, White M, Wheeler AJ (2007) Hydrodynamics and cold-water coral facies distribution related to recent sedimentary processes at Galway Mound west of Ireland. Mar Geol 244:184-195

> Duineveld GCA, Lavaleye MSS, Berghuis EM (2004) Particle flux and food supply to a seamount cold-water coral community (Galicia Bank, NW Spain). Mar Ecol Prog Ser 277: $13-23$

Dungan JL, Perry JN, Dale MRT, Legendre T and others (2002) A balanced view of scale in spatial statistical analysis. Ecography 25:626-640
Durrieu de Madron X, Zervakis V, Theocharis A, Georgopoulos D (2005) Comments on 'Cascades of dense water around the world ocean'. Prog Oceanogr 64:83-90

Edinger E, Baker K, Devillers R, Wareham V (2007) Deep-sea coral distribution and bycatch from commercial fisheries off Newfoundland and Labrador. WWF Canada, Halifax, Nova Scotia

Fautin DG (2002) Reproduction of Cnidaria. Can J Zool 80: $1735-1754$

Fortin MJ, Dale MRT (2005) Spatial analysis: a guide for ecologists. Cambridge University Press, Cambridge

Fosså JH, Mortensen PB, Furevik DM (2000) Lophelia korallrev langs norskekysten forekomst og tilstand. Projektrapport Havforskningsinstituttet, Bergen (in Norwegian with English Abstract)

Frederiksen R, Jensen A, Westerberg H (1992) The distribution of the scleractinian coral Lophelia pertusa around the Faroe Islands and the relation to internal tidal mixing. Sarsia 77:157-171

Freiwald A (2002) Reef-forming cold-water corals. In: Wefer G, Billet D, Hebbeln D, Jørgensen BB, Schlüter M, Van Weering $\mathrm{T}$ (eds) Ocean margin systems. Springer, Berlin, p 365-385

Freiwald A, Beuck L, Rüggeberg A, Taviani M, Hebbeln D (2009) The white coral community in the Central Mediterranean Sea revealed by ROV surveys. Oceanography 22:58-74

Fritchman HK (1974) The planula of the stylasterine hydrocoral Allopora petrograpta (Fisher): it structure, metamorphosis and development of the primary cyclosystem In: Cameron AM, Cambell BM, Cribb AB, Endean R and others (eds) Proc 2nd Int Coral Reef Symp 2:245-258

Gage JD, Bett BJ (2005) Deep-sea benthic sampling In: Eleftheriou A, McIntyre A (eds) Methods for the study of marine benthos, 3rd edn. Blackwell Science, Oxford, p 273-325

Galiano EF (1982) Détection et mesure de l'hétérogénéité spatiale des espèces dans les pâturages. Acta Oecol Oecol Plant 3:269-278

Gass S (2002) An assessment of the distribution and status of deep-sea corals in Atlantic Canada by using both scientific and local forms of knowledge. MS thesis, Dalhousie University, Halifax, Nova Scotia

Gili JM, Coma R (1998) Benthic suspension feeders: their paramount role in littoral marine food webs. Trends Ecol Evol 13:316-321

> Grasmueck M, Eberli GP, Viggiano DA, Correa T, Rathwell G, Luo J (2006) Autonomous underwater vehicle (AUV) mapping reveals coral mound distribution, morphology, and oceanography in deep water of the Straits of Florida. Geophys Res Lett 33:L23616, doi: 10.1029/2006GL027734

Grassle JF, Grassle JP (1992) Notes from the abyss: the effects of a patchy of organic material and larvae on softsediment benthic communities. In: Giller P, Hildrew A, Rafaelli D (eds) Aquatic ecology: scale, pattern and process. 34th Symp Br Ecol Soc, Blackwell, Oxford, p 499-515

Grassle JF, Morse-Porteous LS (1987) Macrofaunal colonization of disturbed deep-sea environments and the structure of deep-sea benthic communities. Deep-Sea Res Part A 34: 1911-1950

Greig-Smith P (1961) Data on pattern within plant communities. I. The analysis of pattern. J Ecol 49:695-702

> Grigg RW (1984) Resource management of precious corals: a review and application to shallow water reef building corals. PSZNI: Mar Ecol 5:57-74

Haase P (1995) Spatial pattern analysis in ecology based on Ripley's K function: introduction and methods of edge correction. J Veg Sci 6:575-582 
Haase P, Pugnaire FI, Clark SC, Incoll LD (1996) Spatial patterns in a two-tiered semi-arid shrubland in south eastern Spain. J Veg Sci 7:527-534

Hall-Spencer J, Allain V, Fosså JH (2002) Trawling damage to Northeast Atlantic ancient coral reefs. Proc R Soc Lond B Biol Sci 269:507-511

Hall-Spencer J, Rogers A, Davies J, Foggo A (2007) Deep-sea coral distribution on seamounts, oceanic islands, and continental slopes in the Northeast Atlantic. Bull Mar Sci 81:135-146

- Highsmith RC (1982) Reproduction by fragmentation in corals. Mar Ecol Prog Ser 7:207-226

Hill MO (1973) The intensity of spatial pattern in plant communities. J Ecol 61:225-235

Keller NB, Os'kina NS (2008) Habitat temperature ranges of azooxantellate scleractinian corals in the world ocean. Oceanology 48:77-84

Kershaw KA (1958) An investigation of the structure of a grassland community. I. The pattern of Agrostis tenuis. J Ecol 46:571-592

Kershaw KA (1960) The detection of pattern and association. J Ecol 48:233-242

Lastras G, Canals M, Urgeles R, Amblas D and others (2007) A walk down the Cap de Creus canyon, northwestern Mediterranean Sea: recent processes inferred from morphology and sediment bedforms. Mar Geol 246:176-192

Le Danois E (1948) Les profondeurs de la mer. Payot, Paris

Le Goff-Vitry MC, Rogers AD (2005) Molecular ecology of Lophelia pertusa in the NE Atlantic In: Freiwald A, Roberts JM (eds) Cold-water corals and ecosystems. Springer-Verlag, Berlin, p 653-662

Lincoln RJ, Boxshall GA, Clark PF (1982) A dictionary of ecology, evolution and systematics. Cambridge University Press, Cambridge

> Lissner AL, Taghon GL, Diener DR, Schroeter SC, Dixon JD (1991) Recolonization of deep-water hard-substrate communities: potential impacts from oil and gas development. Ecol Appl 1:258-267

Ludwig JA, Reynolds JF (1988) Statistical ecology. John Wiley, New York

Lumsden SE, Hourigan TF, Bruckner AW, Dorr G (eds) (2007) The state of deep coral ecosystems of the United States. NOAA Tech Memo CRCP-3, Silver Spring, MD

McCulloch MT, Taviani M, Montagna P, Mortimer G, Remia A (2006) Proliferation and demise of Mediterranean deepsea corals. Geochim Cosmochim Acta 70(Suppl 1):A407 doi:10.1016/j.gca.2006.06.821

> Mienis F, de Stigter HC, White M, Duineveld G, de Haas H, van Weering TCE (2007) Hydrodynamic controls on coldwater coral growth and carbonate mound development at the SW and SE Rockall Trough Margin, NE Atlantic Ocean. Deep-Sea Res I 54:1655-1674

Millot C, Crépon M (1981) Inertial fluctuations on the continental shelf of the Gulf of Lions: observations and theory. J Phys Oceanogr 11:639-657

Mortensen PB, Buhl-Mortensen L (2004) Distribution of deepwater gorgonian corals in relation to benthic habitat features in the Northeast Channel (Atlantic Canada). Mar Biol 144:1223-1238

Mortensen PB, Buhl-Mortensen L, Gordon DC, Fader GBJ, McKeown DL, Fenton DG (2005) Effects of fisheries on deepwater gorgonian corals in the Northeast Channel, Nova Scotia. In: Barnes PW, Thomas JP (eds) Benthic habitats and the effects of fishing. Am Fish Soc Symp 41:369-382

> Ogston AS, Drexler TM, Puig P (2008) Sediment delivery, resuspension, and transport in two contrasting canyon environments in the southwest Gulf of Lions. Cont Shelf Res 28:2000-2016
Ostarello GL (1976) Larval dispersal in the subtidal hydrocoral Allopora californica Verill (1866) In: Mackie GO (ed) Coelenterate ecology and behaviour. Plenum Press, New York

Palanques A, Durrieu de Madron X, Puig P, Fabres J and others (2006) Suspended sediment fluxes and transport processes in the Gulf of Lions submarine canyons. The role of storms and dense water cascading. Mar Geol 234:43-61

> Palanques A, Guillén J, Puig P, Durrieu de Madron X (2008) Storm-driven shelf-to-canyon suspended sediment transport at the southwestern end of the Gulf of Lions. Cont Shelf Res 28:1947-1956

Parrish FA (2007) Density and habitat of three deep-sea corals in the lower Hawaiian chain. In: George RY, Cairns SD (eds) Conservation and adaptative management of seamount and deep-sea coral ecosystems. Rosentiel School of Marine and Atmospheric Science, University of Miami, FL p 185-194

Pérès JM (1982) Major benthic assemblages. In: Kinne O (ed) Marine ecology, Vol 5. Ocean management, Part I. John Wiley, Chichester, p 373-522

Pérès JM, Picard J (1964) Nouveau manuel de bionomie benthique de la mer Mediterranée. Extrait du recueil des travaux de la Station Marine d'Endoume. Rec Trav Stn Endoume 31:5-137

> Puig P, Palanques A, Orange DL, Lastras G, Canals M (2008) Dense shelf water cascades and sedimentary furrow formation in the Cap de Creus Canyon, north-western Mediterranean Sea. Cont Shelf Res 28:2017-2030

Reed JK (1992) Comparison of deep-water Oculina and Lophelia coral banks off Southeastern USA. Proc Am Acad Underwat Sci 12th Annu Sci Diving Symp, p 43-151

Reyss D (1971) Les canyons sous-marins de la mer catalane, le rech du cap et le rech Lacaze-Duthiers. III. Les peuplements de macrofaune benthique. Vie Milieu 22:529-613

Ripley BD (1976) The second-order analysis of stationary processes. J Appl Probab 13:255-266

Ripley BD (1981) Spatial statistics. John Wiley, Hoboken, NJ

Roberts JM, Wheeler AJ, Freiwald A (2006) Reefs of the deep: the biology and geology of cold-water coral ecosystems. Science 312:543-547

Rogers AD (1999) The biology of Lophelia pertusa (Linnaeus 1758) and other deep-water reef-forming corals and impacts from human activities. Int Rev Hydrobiol 84: 315-406

Rogers CS (1990) Responses of coral reefs and reef organisms to sedimentation. Mar Ecol Prog Ser 62:185-202

Rosenberg MS (2008) PASSaGE: pattern analysis, spatial statistics, and geographic exegesis, Version 2. Available at www.passagesoftware.net

Ruggeberg A, Fietzke J, Liebetrau V, Eisenhauer A, Dullo WC, Freiwald A (2008) Stable strontium isotopes $\left(\delta^{88 / 86} \mathrm{Sr}\right)$ in cold-water corals - a new proxy for reconstruction of intermediate ocean water temperatures. Earth Planet Sci Lett 269:570-575

Sánchez F, Serrano A, Gómez Ballesteros M (2009) Photogrammetric quantitative study of habitat and benthic communities of Deep Cantabrian Sea hard grounds. Cont Shelf Res 29(8)1174-1188

Schroeder WW (2007) Seabed characteristics and Lophelia pertusa distribution patterns at sites in the northern and eastern Gulf of Mexico. In: George RY, Cairns SD (eds) Conservation and adaptative management of seamount and deep-sea coral ecosystems. Rosentiel School of Marine and Atmospheric Science, University of Miami, FL, p 315-323

Taviani MA, Freiwald A, Zibrowius H (2005a) Deep coral growth in the Mediterranean Sea: an overview. In: Frei- 
wald A, Roberts JM (eds) Cold-water corals and ecosystems. Springer-Verlag, Berlin, p 137-156

Taviani M, Remia A, Corselli C, Freiwald A and others (2005b) First geo-marine survey of living cold-water Lophelia reefs in the Ionian Sea (Mediterranean basin). Facies 50:409-417

Tursi A, Mastrototaro F, Matarrese A, Maiorano P, D'Onghia G (2004) Biodiversity of the white coral reefs in the Ionian Sea (Central Mediterranean). Chem Ecol 20(Suppl):107-116

Waller RG, Tyler PA (2005) The reproductive biology of two deep-water, reef-building scleractinians from the NE Atlantic Ocean. Coral Reefs 24:514-522

Wareham VE, Edinger EN (2007) Distribution of deep-sea corals in the Newfoundland and Labrador region, Northwest Atlantic Ocean. In: George RY, Cairns SD (eds) Conservation and adaptative management of seamount and deep-sea coral ecosystems. Rosentiel School of Marine and Atmospheric Science, University of Miami, FL, 289-314

Submitted: February 27, 2009; Accepted: September 4, 2009
White M, Mohn C, de Stigter H, Mottram G (2005) Deepwater coral development as a function of hydrodynamics and surface productivity around the submarine banks of the Rockall Trough, NE Atlantic. In: Freiwald A, Roberts JM (eds) Cold-water corals and ecosystems. Springer-Verlag, Berlin, p 503-514

White M, Roberts JM, van Weering T (2007) Do bottomintensified diurnal tidal currents shape the alignment of carbonate mounds in the NE Atlantic? Geo Mar Lett 27: 391-397

Wienberg C, Hebbeln D, Fink HG, Mienis F and others (2009) Scleractinian cold-water corals in the Gulf of Cádiz-first clues about their spatial and temporal distribution. DeepSea Res I 56:1873-1893

Yoshioka PM, Yoshioka BB (1989) A multispecies, multiscale analysis of spatial pattern and its application to a shallowwater gorgonian community. Mar Ecol Prog Ser 54: $257-264$

Proofs received from author(s): November 20, 2009 